\title{
Traumatic submacular hemorrhage: available treatment options and synthesis of the literature
}

\author{
Giamberto Casini ${ }^{1 \dagger}$, Pasquale Loiudice ${ }^{1 *+} \oplus$, Martina Menchini ${ }^{1}$, Francesco Sartini ${ }^{1}$, Stefano De Cillà2, \\ Michele Figus ${ }^{1}$ and Marco Nardi ${ }^{1}$
}

\begin{abstract}
Sub-macular hemorrhage (SMH) is a hematic collection between the neurosensory retina and the retinal pigment epithelium; one of its causes is ocular blunt trauma, that usually affects young patients. Persisting SMH leads to a damage of photoreceptors mediated by three main mechanisms: iron-related toxicity, impairment of diffusion of oxygen and nutriment, mechanical damage due to clot contraction. Since early photoreceptors' damage has been reported within $24 \mathrm{~h}$, it is suggested to provide an early treatment, although there are no guidelines or consensus between authors regarding treatment strategies. The aim of this review was to present and compare available treatment options, like intravitreal tissue plasminogen activator (tPA) associated with pneumatic displacement, pneumatic displacement alone, subretinal tPA injection with pneumatic displacement, and intravitreal anti-vascular endothelial growth factor (VEGF) injection. All procedures obtained consistent results, though the most effective seemed to be pars plana vitrectomy, subretinal tPA and gas tamponade, probably due to a quicker liquefaction and displacement of the clot. Limitations concern the greater invasiveness and the higher incidence of complications. Alternatively, intravitreal injection of tPA and gas may represent a less invasive option with fewer complications. Intravitreal injection of gas and prone position could be preferred in young patients without coexisting ocular pathology, being a minimally invasive treatment, with lower risk of complications and a good visual recovery. Anti-VEGF agent have found, to date, limited employment in cases of traumatic SMH even though they may be useful as alternative or adjuvant therapy. Most of the published literature consists of small studies and case reports, therefore further investigations and larger clinical trials are required to fully understand safety and efficacy of the procedures. A preoperative comprehensive evaluation may be helpful to realize a surgical plan tailored on patient.
\end{abstract}

Keywords: Anti-vascular endothelial grow factor, Blunt ocular trauma, Pneumatic displacement, Vitrectomy, Submacular hemorrhage, Tissue plasminogen activator

\section{Introduction}

Sub-macular hemorrhage (SMH) is defined as blood collection between the neurosensory retina and the retinal pigment epithelium (RPE) (Fig. 1). It can be caused by several conditions, including age-related macular degeneration, pathologic myopia, polypoidal choroidal

\footnotetext{
*Correspondence: Idcpasquale@gmail.com

${ }^{\dagger}$ Giamberto Casini and Pasquale Loiudice contributed equally to this work

${ }^{1}$ Ophthalmology Unit, Department of Surgical, Medical, Molecular

and Critical Area Pathology, University of Pisa, Pisa, Italy

Full list of author information is available at the end of the article
}

vasculopathy, macroaneurysms, presumed ocular histoplasmosis syndrome, and blunt trauma [1-5].

In pediatric age, the incidence of eye trauma has been reported to be $8.9-15.2 / 100000$ per year and about $62-65 \%$ of hospitalized trauma patients have blunt ocular trauma compared to $16-28 \%$ with an open-globe injury $[6,7]$. Blunt ocular trauma, usually affecting young patients during sport activity or after episodes of violence, may lead to several pathologic consequences such as commotio retinae, choroidal rupture, macular hole, subretinal hemorrhage, retinal vascular occlusion, vitreous hemorrhage, retinal pigment epithelial edema, retinal 


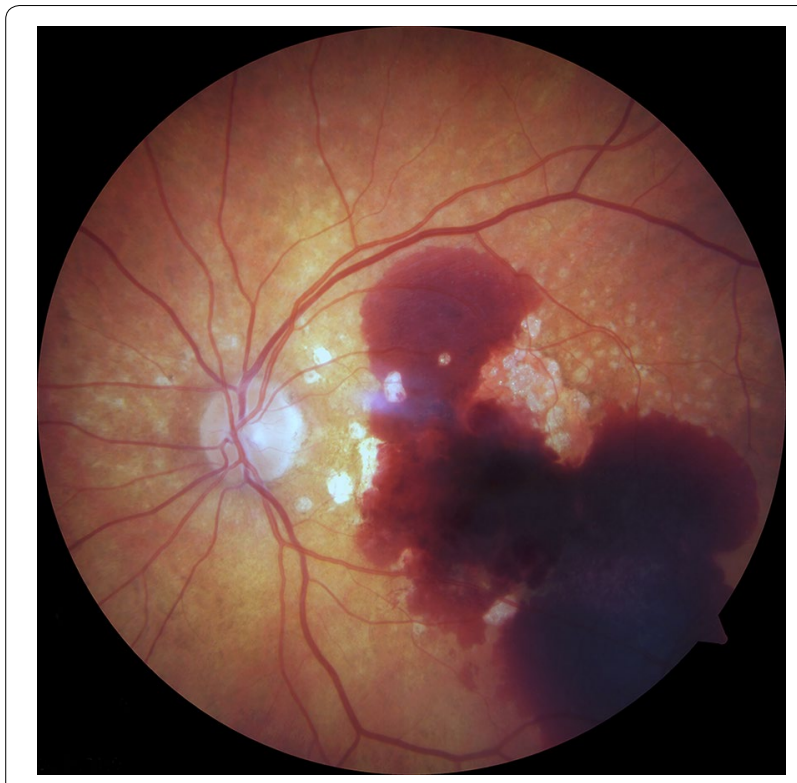

Fig. 1 Fundus photograph of a patient with large submacular hemorrhage extending beyond the temporal vascular arcades

dialysis, macular infarction, traumatic optic neuropathy and optic nerve avulsion [8-13].

In case of choroid rupture, the fracture usually runs parallel and temporal to the optic disk, with macula involvement in $66 \%$ of cases [14]. SMH, subsequent to choroidal rupture in macular region, is a sight-threatening condition, and is associated with poor visual outcome, especially if SMH persists for several days [15].

SMH may be classified according to the size: a small SMH measures less than 4 disc diameters, a medium-size SMH has a diameter greater than 4 disc diameters but does not extend beyond the temporal vascular arcade, a massive SMH overspreads the temporal vascular arcade [16].

Prompt treatment of SMH is recommended, even though there are no guidelines or consensus between authors regarding treatment strategies.

\section{Pathogenesis}

Most of information regarding the pathogenesis of the damage SMH-related derived from animal models. Early hematic toxic effect can be demonstrated already $1 \mathrm{~h}$ after SMH onset in experimental rabbit models, consisting in edematous appearance of some photoreceptors [17]. Proceeding from day 1 to day 7, progressive damage was observed. Photoreceptor aspect ranged from edematous to absent, with pyknosis and karyolysis of the outer nuclear layer. At 2 weeks most of the clot was reabsorbed; photoreceptors and outer nuclear layer were completely absent; karyolysis of the inner nuclear layer was registered [17].

Macular damage due to SMH consists of a combination of multiple mechanisms. Blood coagulation produces erythrocyte degeneration, with release of iron and hemosiderin, and subsequent oxidative stress. Labile iron is one of the key factors for oxidative damage to cellular proteins, lipids, nucleic acids, and other cellular constituents [18]. Iron-mediated toxicity causes selective destruction of the first retinal neuron and has effects on retinal circulation [19]. Blood clot behaves like a barrier to metabolic exchange and limits the passage of nutrient and oxygen from the RPE to the photoreceptors. Since the metabolism of the photoreceptor is strongly related to RPE cell activity, this may explain because the former is more susceptible to the barrier effect [20]. Chemotaxis of macrophages and fibroblasts leads to release of inflammatory mediators and fibrin, leading to scar formation. Moreover, the clot in subretinal space adheres to photoreceptor; due to clot's contraction, an avulsion of photoreceptor may occur [17, 20-24]. For this reason caution is suggest when a surgeon attempt to directly remove the clot from subretinal space.

\section{Prognostic factors}

The natural history of SMH is poor, with final visual acuity ranging from $20 / 200$ to light perception [25]. Visual prognosis depends on baseline visual acuity (VA), hemorrhage's size and location, interval between SMH onset and treatment, concomitant involvement of anterior or posterior segment (e.g. iridodialysis, lens dislocation, traumatic cataract, vitreous hemorrhage and ciliary body clefts) [26-28].

Poor visual acuity at SMH onset, greater than 1.00 $\log$ MAR, is associated with poor functional outcome at 6 months [29]. Persistent SMH (more than 2 months) is related with worse final visual acuity [29]. The location and the extension of the hemorrhage are related with the functional recovery, especially in cases of massive SMH extending beyond the vascular arcades [30]. Contrarily, small size hemorrhage and younger age are predictor factors for better outcome [31]. Concomitant macular disease like polypoidal choroidal vasculopathy and age-related macular degeneration may influence the functional prognosis, being the former condition more inclined to recurrent hemorrhages, and the latter to the development of subretinal fibrosis [32-34].

Optical coherence tomography (OCT) can provide supplementary prognostic factors, such as retinal inner segment/outer segment layer integrity, foveal thickness and $\mathrm{SMH}$ area [35]. Intraoperative OCT can be used to identify the ideal location for needle penetration, and to grade the impact of surgical maneuvers on the retinal 
architecture [36]. During follow-up, OCT can be performed to estimate residual sub-macular blood and to assess the integrity of the underlying RPE in the choroidal rupture's setting [28, 36-38].

\section{Therapeutic options}

Management of traumatic SMH evolved over time and different approaches have been attempted, like intravitreal or subretinal injection of recombinant tissue plasminogen activator (tPA), intravitreal gas injection, a combination of them or intravitreal injections of anti-vascular endothelial growth factor (VEGF) agents (Table 1).

\section{Intravitreal tissue plasminogen activator injection with pneumatic displacement}

In 1996 Chen et al. [39] introduced a method involving the intravitreal injection of tPA and gas to displace the blood away from the macula. tPA is a recombinant serine protease which lyses serine residues in plasminogen, activating it into plasmin, enhancing fibrinolysis [40]. The procedure started with dilated fundus exam to check central retinal artery perfusion; then, an anterior chamber paracentesis is realized to prevent an intraocular pressure spike. Finally, an intravitreal injection of tPA is performed, followed by $0.2-0.5 \mathrm{ml}$ of sulfur hexafluoride (SF6) or perfluoropropane (C3F8) gas [28, 38]. After the procedure, the patient should maintain a face down position to support blood displacement [21,28]. The ideal time interval between injecting intravitreal tPA and starting prone positioning is still debated [21]. The procedure aims to boost enzymatic liquefaction of sub-macular clot with intravitreal tPA, reducing hematic toxic effect, meanwhile long-acting expansile gas generates a pneumatic displacement of the blood, away from the macula [41-43].

How intravitreal tPA can diffuse into subretinal space has not been sufficiently clarified [44, 45]. Actually, Kamei et al. [46] demonstrated that tPA does not diffuse through intact retina in rabbit models. It has been speculated that TPA could pass through retinal micro-lesions and focal breaks in the internal limiting membrane, due to retinal stretching, caused by the hemorrhage itself. In an experimental rabbit model, Coll and colleagues

Table 1 Clinical data and treatment results in patients with traumatic sub macular hemorrhage

\begin{tabular}{|c|c|c|c|c|c|c|}
\hline Author & No. of eyes & Treatment & Dose & Baseline BCVA & Final BCVA & $\begin{array}{l}\text { Follow-up } \\
\text { (months) }\end{array}$ \\
\hline \multirow[t]{3}{*}{ Balughatta et al. [22] } & \multirow[t]{3}{*}{3} & \multirow[t]{3}{*}{ Intravitreous C3F8 } & \multirow[t]{3}{*}{$0.3 \mathrm{ml}$} & CF & $20 / 30$ & \multirow[t]{3}{*}{3} \\
\hline & & & & $C F$ & $20 / 40$ & \\
\hline & & & & $20 / 60$ & $20 / 90$ & \\
\hline \multirow[t]{5}{*}{ Ohji et al. [55] } & \multirow[t]{5}{*}{5} & \multirow[t]{5}{*}{ Intravitreous C3F8 } & $0.4 \mathrm{ml}$ & $20 / 400$ & $20 / 15$ & 14 \\
\hline & & & $0.4 \mathrm{ml}$ & $20 / 300$ & $20 / 40$ & 6 \\
\hline & & & $0.5 \mathrm{ml}$ & $20 / 2000$ & $20 / 200$ & 13 \\
\hline & & & $0.4 \mathrm{ml}$ & $20 / 400$ & $20 / 50$ & 3 \\
\hline & & & $0.4 \mathrm{ml}$ & $20 / 700$ & $20 / 200$ & 3 \\
\hline \multirow[t]{4}{*}{ Gopalakrishan et al. [54] } & \multirow[t]{4}{*}{4} & \multirow[t]{4}{*}{ Intravitreal C3F8 } & \multirow[t]{4}{*}{$0.3 \mathrm{ml}$} & CF & $20 / 20$ & \multirow[t]{4}{*}{3} \\
\hline & & & & CF & $20 / 63$ & \\
\hline & & & & $20 / 125$ & $20 / 125$ & \\
\hline & & & & CF & $20 / 20$ & \\
\hline Tsuyama et al. [48] & 1 & Intravitreous tPA + SF6 & $12.5 \mu \mathrm{g} / 0.05 \mathrm{ml}+0.3 \mathrm{ml}$ & $20 / 70$ & $20 / 16$ & 4 \\
\hline \multirow[t]{2}{*}{ Araújo et al. [42] } & \multirow[t]{2}{*}{2} & \multirow[t]{2}{*}{ Intravitreous tPA + SF6 } & \multirow[t]{2}{*}{$50 \mu \mathrm{g} / 0.05 \mathrm{ml}+0.3 \mathrm{ml}$} & $20 / 63$ & $20 / 20$ & \multirow[t]{2}{*}{4} \\
\hline & & & & $20 / 200$ & $20 / 32$ & \\
\hline Hassan et al. [21] & 1 & Intravitreous tPA + SF6 & $75 \mu \mathrm{g} / 0.15 \mathrm{ml}+0.4 \mathrm{ml}$ & $20 / 200$ & $20 / 30$ & 9 \\
\hline \multirow[t]{2}{*}{ Holland et al. [49] } & \multirow[t]{2}{*}{2} & \multirow{2}{*}{$\begin{array}{l}\text { Intravitreous tPA + SF6 } \\
\text { SF6 alone }\end{array}$} & \multirow{2}{*}{$\begin{array}{l}50 \mu \mathrm{g}+0.4 \mathrm{ml} \\
0.4 \mathrm{ml}\end{array}$} & $20 / 125$ & $20 / 32$ & 12 \\
\hline & & & & $20 / 100$ & $20 / 32$ & 12 \\
\hline Kung et al. [41] & 1 & Intravitreal tPA + C3F8 & $50 \mu \mathrm{g}+0.3 \mathrm{ml}$ & & & \\
\hline \multirow[t]{2}{*}{ Buschini et al. [38] } & \multirow[t]{2}{*}{2} & Subretinal tPA & $25 \mu \mathrm{g} / 0.1 \mathrm{ml}$ & $20 / 100$ & $20 / 20$ & 3 \\
\hline & & Intravitreous tPA + SF6 & $50 \mu \mathrm{g}+0.4 \mathrm{ml}$ & $20 / 125$ & $20 / 63$ & 5 \\
\hline Doi et al. [60] & 1 & Subretinal tPA & $6.9 \mu \mathrm{g} / 0.1 \mathrm{ml}$ & $\mathrm{HM}$ & $20 / 40$ & 3 \\
\hline Hillenkamp et al. [52] & 1 & Subretinal tPA + SF6 & $10-20 \mu \mathrm{g} / 0.05-0.1 \mathrm{ml}$ & $20 / 125$ & $20 / 25$ & 3 \\
\hline Abdul-Salim et al. [81] & 1 & Intravitreal ranibizumab & $0.5 \mathrm{mg}$ & CF & $20 / 63$ & 3 \\
\hline
\end{tabular}


observed liquefaction of a 1-day-old subretinal clot within $24 \mathrm{~h}$ after intravitreal TPA injection [44]. Kimura et al. [47] reported complete liquefaction of acute subretinal blood in 6 patients with age-related macular degeneration treated with intravitreal tPA $12-36 \mathrm{~h}$ before surgical evacuation of the blood.

Tsuyama et al. [48] published a case report of a 10-yearold male, with traumatic SMH treated with intravitreal tPA injection $(12.5 \mu \mathrm{g}$ in $0.05 \mathrm{ml})$ followed by $0.3 \mathrm{ml}$ of pure SF6 injection to obtain SMH pneumatic displacement. The procedure was performed with no complications. His baseline VA was 20/70, and improved to 20/16 at 4 month of follow up.

Araújo et al. [42] reported a case series of 6 eyes with $\mathrm{SMH}, 2$ of which due to blunt trauma. All subjects were treated with intravitreal tPA and SF6 achieving a displacement of macular hemorrhage and an improvement of visual acuity.

Hassan et al. [21] treated 15 eyes with acute SMH, one of them was secondary to a blunt trauma. The patient had a 20/200 baseline VA and was treated with $75 \mu \mathrm{g}$ of intravitreal tPA followed by SF6 injection and 3 day of prone position. Final VA was 20/30 at 9 months of follow-up.

The technique described is cheap and provides a minimum surgical stress to RPE and photoreceptors. Adverse events are rare but could be serious, and include vitreous hemorrhage, hyphema and rebleeding, especially if tPA is injected into fresh hemorrhage, less than 3 days old [49-51]. Remarkably, tPA could provoke retinal toxicity, leading to retinal necrosis and photoreceptors loss. For these reasons, it is recommended to avoid intravitreal dose $>50 \mu \mathrm{g}[21,39,52]$.

\section{Pneumatic displacement}

Due to tPA retinal toxicity, gas displacement alone, followed by face down position, has been proposed for the treatment of traumatic SMH [53]. Gopalakrishan et al. [54] investigated a series of 20 patients with sub macular hemorrhage due to different causes, among which four cases of ocular blunt trauma and a variable visual acuity from hand motion to 20/125. All patients were treated with an intravitreal $0.3-\mathrm{ml}$ injection of pure C3F8 and face down positioning for 5-7 days. Displacement occurred partially or completely in 16 of 20 eyes, and visual acuity remained stable in all eyes during the first year of follow-up. Authors advice to perform this procedure in subjects with symptoms onset less than 30 days.

In a case series of 3 patients with post-traumatic SMH, Balughatta et al. [22] used $0.3 \mathrm{ml}$ of intravitreal pure C3F8, obtaining significant displacement of the SMH and visual recovery in 2 of the 3 cases.

Ohji et al. [55] described a series of five patients treated with $0.4-0.5 \mathrm{ml}$ of pure C3F8 and face down positioning with a complete or partial displacement in all eyes. The authors advise to carry out the treatment within a week of $\mathrm{SMH}$ onset, otherwise gas displacement alone could be ineffective.

Holland et al. [49] compared $50 \mu \mathrm{g}$ of tPA followed by $0.04 \mathrm{ml}$ of pure SF6 injection versus $0.04 \mathrm{ml}$ of pure SF6 injection alone in 2 cases of SMH subsequent to choroidal rupture. VA of the patient treated with the combined procedure improved from 20/125 to 20/63 after 6 days and 20/32 after 10 weeks, stable at 1 year of follow-up. The patient treated with gas alone had a baseline VA of 20/100, improved to $20 / 32$ after 2 months and remained stable at 1 year of follow up. No adverse events were reported in any patient. Both procedures seemed similar in terms of VA improvement, but a combined procedure could result in a faster recovery.

Pneumatic displacement induces an inferior surgical stress compared to intravitreal tPA injection. Interestingly, its efficacy seems to be related to the interval time between SMH onset and treatment. Further investigations are needed to confirm this assumption.

\section{Subretinal injection of tissue plasminogen activator with pneumatic displacement}

The tPA can be injected into subretinal space during a pars plana vitrectomy (PPV), using a 41-gauge needle to release $0.1 \mathrm{ml}$ of tPA, followed by gas tamponade $[38,52$, 56].

The technique was first described by Haupert et al. [57] in 2001 who injected tPA directly into subretinal clot using a bent 36 -gauge needle. The procedure allows tPA to act with a higher concentration, locally at the site of the hemorrhage, enhancing its fibrinolytic action. At the end of the procedure an intravitreal gas injection aims to displace the blood clot away from the macula. The patient should maintain face down position for at least $24 \mathrm{~h}$ [58, 59].

Buschini et al. [38] compared two cases of ocular blunt trauma with $\mathrm{SMH}$ development, the first one treated with subretinal injection of tPA $(25 \mu \mathrm{g}$ in $0.1 \mathrm{ml})$ after PPV and the other one with an intravitreal injection of $50 \mu \mathrm{g}$ of tPA and $0.4 \mathrm{ml}$ of SF6. The first patient, with 20/100 baseline VA, showed a fast blood reabsorption with an optimal VA outcome (20/20) at 3 months postoperatively. The second patient, with baseline VA of 20/125, showed a persistence of hyperreflective subfoveal fluid on OCT, 1 month after the procedure, with VA of 20/63. At 5 months of follow-up, OCT highlighted focal gaps in photoreceptor layers. Authors speculated that the slower recovery entailed the development of retinal toxicity due to erythrocyte degeneration, compromising the outcome.

In a 13-years-old boy with a traumatic SMH, Doi et al. [60] performed a PPV followed by subretinal 
tPA $(6.9 \mu \mathrm{g}$ in $0.1 \mathrm{ml})$ injection. Baseline VA was hand motion. One month after the procedure, due to lens opacity, cataract surgery was executed, in association with intravitreal anti-VEGF injection $(0.05 \mathrm{ml}$ bevacizumab), to prevent choroidal neovascularization. At 3 months of follow-up, VA was 20/40 without any other adverse events.

Martel et al. [61] proposed a different therapeutic approach, injecting into subretinal space an association of $0.4 \mathrm{ml}$ of tPA at a concentration of $12.5 \mu \mathrm{g} / 0.1 \mathrm{ml}$ (total, $50 \mu \mathrm{g}$ ), $0.1 \mathrm{ml}$ of bevacizumab $(2.5 \mathrm{mg}$ ), and $0.2 \mathrm{ml}$ of filtered air.

Kung et al. [41] in their retrospective case series, treated 46 consecutive eyes with $\mathrm{SMH}$ with $50 \mu \mathrm{g} / 0.1 \mathrm{ml}$ of intravitreal tPA and $0.3 \mathrm{ml} \mathrm{C} 3 \mathrm{~F} 8$. SMH was due to various etiologies such as AMD, PCV, retinal arterial macroaneurysms and ocular trauma (1 case).

In a retrospective, comparative series, Hillenkamp et al. [52] divided their 47 patients in 2 groups, receiving either intravitreal $40 \mu \mathrm{g}$ of tPA $+20 \%$ SF6 (group A) or subretinal $10-20 \mu \mathrm{g}$ of tPA $+20 \%$ SF6 (group B). One of the cases was due to ocular trauma and was included in group B. The authors concluded that treatment B was more effective in terms of hemorrhage displacement and visual recovery but was affected by a higher rate of complications.

The rationale was to maximize hemorrhage displacement within submacular space, acting on friction, gravity and buoyancy, that are the main forces responsible for blood displacement. Friction is reduced by hemorrhage liquefaction due to tPA; upright positioning enhances the gravitational force for inferior $\mathrm{SMH}$ displacement; subretinal air bubble decreases SMH buoyancy, allowing a more effective hemorrhage inferior displacement, based on Archimedes' principle. At the end of the procedure, the vitreous cavity was filled in half with SF6 20\%, to keep subretinal air within the macula, and patient should maintain a post-operatory upright position. The procedure may be preferred if SMH does not reach one or both temporal arcade and in case of patients unable to maintain a prone position [61].

Subretinal injection of tPA followed by SF6 tamponade seems to be more effective in terms of visual outcome, when compared to intravitreal tPA injection; nevertheless, it is a more complex surgical maneuver that requires specific surgical skills. Furthermore, it is associated with an increased risk of adverse events, like retinal detachments, cataract development, endophthalmitis, choroidal neovascularization, cystoid macular edema, elevated intraocular pressure or hypotony, pupillary block/angle closure secondary to gas tamponade $[52,62,63]$.

\section{Anti-VEGF agents injections}

The anti-vascular endothelial growth factor agents are commonly used to treat neovascular AMD, PCV and proliferative diabetic retinopathy, but recently their therapeutic role in patients with choroidal neovascularization, due to traumatic choroidal rupture, has been analyzed, associated or not with pneumatic displacement $[61,64,65]$.

Although there are several papers reporting the use of anti-VEGF agents, alone or in combination of tPA or gas, for the treatment of SMH secondary to AMD [66-74], PCV [75-78] or retinal macroaneurysms [79, 80], in our bibliographic research we found only one report regarding SMH subsequent to ocular trauma.

Abdul-Salim et al. [81] have been the first to present a case report of a 23-year-old male treated with a single dose of $0.5 \mathrm{mg}$ of intravitreal ranibizumab after $\mathrm{SMH}$, secondary to an ocular blunt trauma. VA was counting fingers at $1 \mathrm{~m}$ and the dilated fundus examination showed a submacular hemorrhage with an increased central macular thickness (CMT) on OCT. Ranibizumab was injected 20 days after the trauma and VA reached $6 / 45$ at 1 month and 6/18 at 3 months follow-up. OCT showed a CMT reduction and a resolution of the SMH.

Ranibizumab might accelerate the resorption of the hemorrhage with a quick recovery of VA, but the exact mechanism is not fully understood. It has been supposed that anti-VEGF drugs have anti-inflammatory properties, downgrading inflammatory response, besides their antiangiogenic effect, that reduces vascular permeability. These mechanisms could explain anti-VEGF effectiveness in treatment of $\mathrm{SMH}$, boosting blood's reabsorption and healing [82-84].

Complications related to intravitreal injection are rare and do not differ from those observed with the use of anti-VEGF drugs for the treatment of other retinal pathologies (i.e. retinal detachment, endophthalmitis, cataract and intraocular pressure elevation) [64].

Anti-VEGF intravitreal injection could be a useful alternative in traumatic SMH treatment, but larger randomized controlled trials are needed to address issues about long-term efficacy and safety.

\section{Conclusion}

Traumatic SMH may have an unfavorable evolution if untreated, especially in young patients with sudden vision loss. Nevertheless, management is not clear and depends on various factors such as patient's age, ocular comorbidities, hemorrhage's size and thickness and interval time between onset and treatment (Fig. 2). Submacular blood persistence causes progressive photoreceptor toxicity, and for this reason it's necessary a patient's thorough 


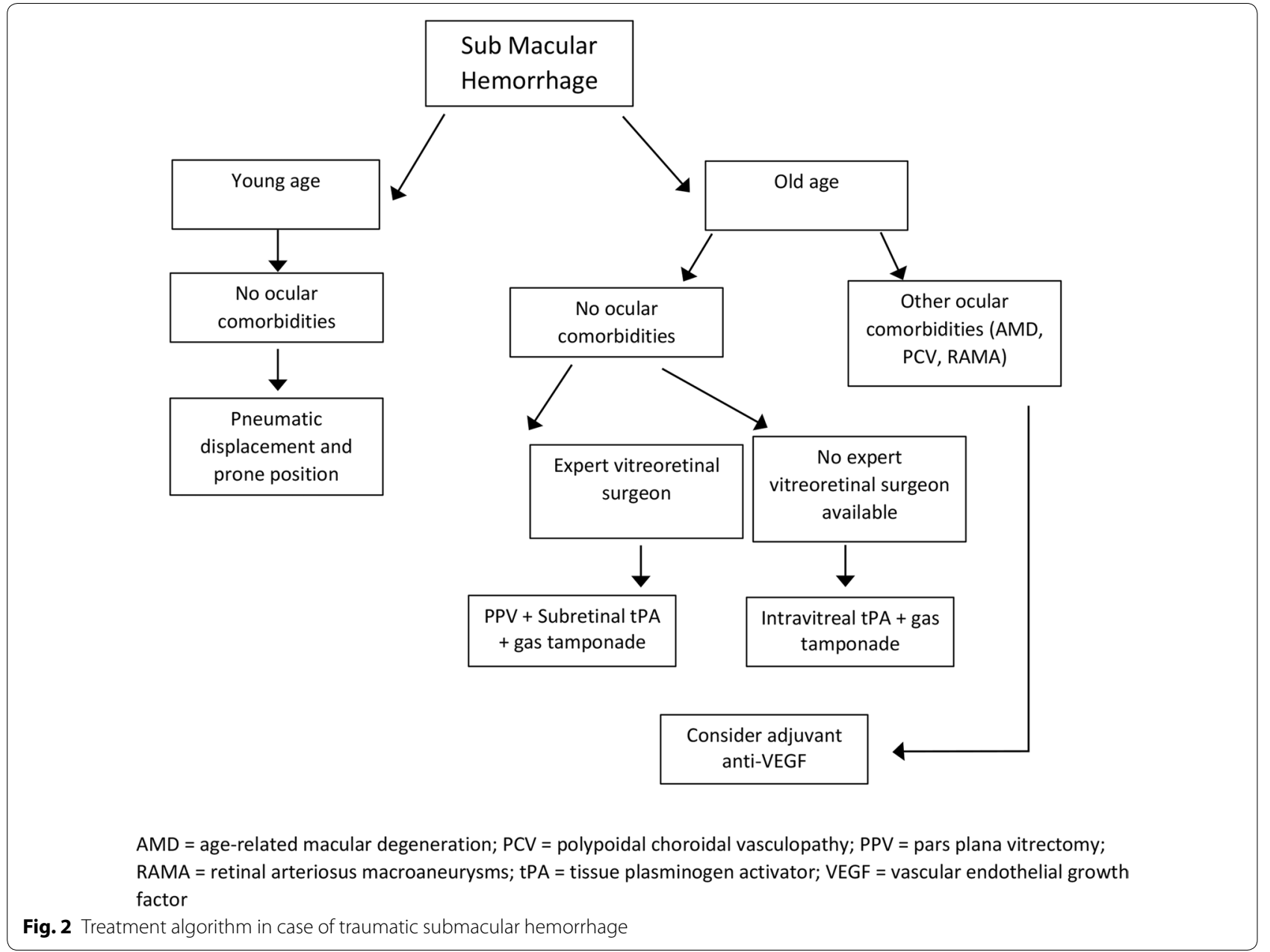

evaluation, to analyze preoperative prognostic factors that can determine the final visual outcome.

All procedures obtained consistent results, though the most effective seemed to be PPV, subretinal tPA and 20\% SF6 injection, probably due to a quicker liquefaction and displacement of the clot. Limitations concern the greater invasiveness and the higher incidence of complications.

Alternatively, intravitreal injection of tPA and 20\% SF6 gas could be a good choice, being less invasive with fewer complications. However, a reduced tPA penetration in the subretinal space, associated with longer blood lasting, could be responsible of lower final VA.

Pneumatic displacement without tPA injection, followed by face down positioning, could be an alternatively treatment in case of young patients without coexisting ocular pathology, being a minimally invasive treatment, with lower risk of complications and morbidity, and a good visual recovery.

Finally, intravitreal anti-VEGF agents have been used successfully to treat submacular hemorrhage due to neovascular AMD, proliferative retinopathy and PCV but few cases, related to ocular trauma, have been described. Results are rising and this treatment could be an alternative or adjuvant therapy to the abovementioned therapy options, however further investigations are warranted to better understand its safety and efficacy.

A limitation of this review was that most of the published literature consists of small studies and case reports, therefore further investigations and larger clinical trials are required to fully understand safety and efficacy of the procedures.

\section{Abbreviations}

SMH: sub-macular hemorrhage; tPA: tissue plasminogen activator; VEGF: vascular endothelial growth factor; RPE: retinal pigment epithelium; VA: visual acuity; OCT: optical coherence tomography; SF6: sulfur hexafluoride SF6; C3F8: perfluoropropane; PPV: a pars plana vitrectomy; CMT: central macular thickness.

\section{Acknowledgements}

Not applicable. 


\section{Authors' contributions}

GC made substantial contributions to the conception of the work. PL drafted the work. MM and FS review the literature. SDC made contributions to interpretation of data. MF and MN substantively revised the manuscript. All authors read and approved the final manuscript.

\section{Funding}

The authors declare that they received no funding.

\section{Availability of data and materials}

Not applicable.

\section{Ethics approval and consent to participate}

Not applicable.

\section{Consent for publication}

Not applicable.

\section{Competing interests}

The authors declare that they have no competing interests.

\section{Author details}

${ }^{1}$ Ophthalmology Unit, Department of Surgical, Medical, Molecular and Critical Area Pathology, University of Pisa, Pisa, Italy. ${ }^{2}$ Department of Health Sciences, Eye Clinic, University of Piemonte Orientale, Novara, Italy.

Received: 12 July 2019 Accepted: 9 November 2019 Published online: 11 December 2019

\section{References}

1. Gibran SK, Romano MR, Wong D. Perfluorocarbon liquid assisted large retinal epithelium patching in sub-macular hemorrhage secondary to age related macular degeneration. Graefes Arch Clin Exp Ophthalmol. 2009;247:187-91.

2. Nayak S, Padhi TR, Basu S, Das T. Pneumatic displacement and intra-vitreal bevacizumab in management of sub-retinal and sub-retinal pigment epithelial hemorrhage at macula in polypoidal choroidal vasculopathy (PCV): rationale and outcome. Semin Ophthalmol. 2015;30:53-5.

3. Thuruthumaly C, Yee DC, Rao PK. Presumed ocular histoplasmosis. Curr Opin Ophthalmol. 2014;25:508-12.

4. Moriyama M, Ohno-Matsui K, Shimada N, Hayashi K, Kojima A, Yoshida T, et al. Correlation between visual prognosis and fundus autofluorescence and optical coherence tomographic findings in highly myopic eyes with submacular hemorrhage and without choroidal neovascularization. Retina. 2011;31:74-80.

5. Nakamura H, Hayakawa K, Sawaguchi S, Gaja T, Nagamine N, Medoruma K. Visual outcome after vitreous, sub-internal limiting membrane, and/or submacular hemorrhage removal associated with ruptured retinal arterial macroaneurysms. Graefes Arch Clin Exp Ophthalmol. 2008;246:661-9.

6. Strahlman E, Elman M, Daub E, Baker S. Causes of pediatric eye injuries. A population-based study. Arch Ophthalmol. 1990;108:603-6.

7. MacEwen CJ, Baines PS, Desai P. Eye injuries in children: the current picture. Br J Ophthalmol. 1999:83:933-6.

8. Friberg TR. Traumatic retinal pigment epithelial edema. Am J Ophthalmol. 1979:88:18-21.

9. Duke-Elder S. System of ophthalmology V. Ophthalmic optics \& refraction. London: Henry Kimpton; 1970.

10. Dalma-Weiszhausz J, Meza-de Regil A, Martinez-Jardon S, Oliver-Fernandez K. Retinal vascular occlusion following ocular contusion. Graefes Arch Clin Exp Ophthalmol. 2005:243:406-9.

11. Umeed S, Shafquat S. Commotio-retinae and central retinal artery occlusion after blunt ocular trauma. Eye. 2004;18:333-4.

12. Goel N, Rajput M, Sawhney A, Sardana T. Macular infarction and traumatic optic neuropathy following blunt ocular trauma. Saudi J Ophthalmol. 2016;30:53-5.

13. Mackiewicz J, Tomaszewska J, Jasielska M. Optic nerve avulsion after blunt ocular trauma_case report. Ann Agric Environ Med. 2016;23:382-3.
14. Wyszynski RE, Grossniklaus HE, Frank KE. Indirect choroidal rupture secondary to blunt ocular trauma. A review of eight eyes. Retina. 1988:8:237-43.

15. Ament CS, Zacks DN, Lane AM, Krzystolik M, D’Amico DJ, Mukai S, et al. Predictors of visual outcome and choroidal neovascular membrane formation after traumatic choroidal rupture. Arch Ophthalmol. 2006:124:957-66.

16. Fine HF, Iranmanesh R, Del Priore LV, Barile GR, Chang LK, Chang S, et al. Surgical outcomes after massive subretinal hemorrhage secondary to age-related macular degeneration. Retina. 2010;30:1588-94.

17. Glatt $\mathrm{H}$, Machemer R. Experimental subretinal hemorrhage in rabbits. Am J Ophthalmol. 1982;94:762-73.

18. Papanikolaou G, Pantopoulos K. Iron metabolism and toxicity. Toxicol Appl Pharmacol. 2005;202:199-211.

19. Imam MU, Zhang S, Ma J, Wang H, Wang F. Antioxidants mediate both iron homeostasis and oxidative stress. Nutrients. 2017:9:671.

20. Hochman MA, Seery CM, Zarbin MA. Pathophysiology and management of subretinal hemorrhage. Surv Ophthalmol. 1997;42:195-213.

21. Hassan AS, Johnson MW, Schneiderman TE, Regillo CD, Tornambe PE, Poliner LS, et al. Management of submacular hemorrhage with intravitreous tissue plasminogen activator injection and pneumatic displacement. Ophthalmology. 1999;106:1900-6 (discussion 6-7).

22. Balughatta P, Kadri V, Braganza S, Jayadev C, Mehta RA, Nakhate V, et al. Pneumatic displacement of limited traumatic submacular hemorrhage without tissue plasminogen activator: a case series. Retin Cases Brief Rep. 2019;13:34-8

23. Toth CA, Morse LS, Hjelmeland LM, Landers MB 3rd. Fibrin directs early retinal damage after experimental subretinal hemorrhage. Arch Ophthalmol. 1991:109:723-9.

24. Bennett SR, Folk JC, Blodi CF, Klugman M. Factors prognostic of visual outcome in patients with subretinal hemorrhage. Am J Ophthalmol. 1990;109:33-7.

25. Scupola A, Coscas G, Soubrane G, Balestrazzi E. Natural history of macular subretinal hemorrhage in age-related macular degeneration. Ophthalmologica. 1999:213:97-102.

26. Berrocal MH, Lewis ML, Flynn HW Jr. Variations in the clinical course of submacular hemorrhage. Am J Ophthalmol. 1996;122:486-93.

27. Viestenz A. Rupture of the choroid after eyeball contusion - an analysis based on the Erlangen Ocular Contusion Registry (EOCR). Klin Monbl Augenheilkd. 2004;221:713-9.

28. Malik FF, Poulaki V. Management of submacular hemorrhage. Int Ophthalmol Clin. 2014:54:51-9.

29. Kunavisarut P, Thithuan T, Patikulsila D, Choovuthayakorn J, Watanachai N, Chaikitmongkol V, et al. Submacular hemorrhage: visual outcomes and prognostic factors. Asia Pac J Ophthalmol. 2018;7:109-13.

30. Vander JF, Federman JL, Greven C, Slusher MM, Gabel VP. Surgical removal of massive subretinal hemorrhage associated with age-related macular degeneration. Ophthalmology. 1991;98:23-7.

31. Lin TC, Hwang DK, Lee FL, Chen SJ. Visual prognosis of massive submacular hemorrhage in polypoidal choroidal vasculopathy with or without combination treatment. J Chin Med Assoc. 2016;79:159-65.

32. Yoon YH, Marmor MF. Rapid enhancement of retinal adhesion by laser photocoagulation. Ophthalmology. 1988:95:1385-8.

33. Sho K, Takahashi K, Yamada H, Wada M, Nagai Y, Otsuji T, et al. Polypoidal choroidal vasculopathy: incidence, demographic features, and clinical characteristics. Arch Ophthalmol. 2003;121:1392-6.

34. Ishikawa K, Kannan R, Hinton DR. Molecular mechanisms of subretinal fibrosis in age-related macular degeneration. Exp Eye Res. 2016;142:19-25.

35. Sampangi R, Hemalatha BC. SD-OCT based management of traumatic sub-macular hemorrhage_our experience. Indian J Ophthalmol. 2013;61:531.

36. Ehlers JP, Petkovsek DS, Yuan A, Singh RP, Srivastava SK. Intrasurgical assessment of subretinal tPA injection for submacular hemorrhage in the PIONEER study utilizing intraoperative OCT. Ophthalmic Surg Lasers Imaging Retina. 2015;46:327-32.

37. Goldman DR, Vora RA, Reichel E. Traumatic choroidal rupture with submacular hemorrhage treated with pneumatic displacement. Retina. 2014:34:1258-60.

38. Buschini E, lannetta D, Lesnik Oberstein SY, Bijl HM, Mura M. Subretinal versus intravitreal injection of recombinant tissue plasminogen 
activator in post-traumatic submacular haemorrhages. Acta Ophthalmol. 2016;94:307-9.

39. Chen CY, Hooper C, Chiu D, Chamberlain M, Karia N, Heriot WJ. Management of submacular hemorrhage with intravitreal injection of tissue plasminogen activator and expansile gas. Retina. 2007;27:321-8.

40. Kamei M, Tano Y. Tissue plasminogen activator-assisted vitrectomy: surgical drainage of submacular hemorrhage. Dev Ophthalmol. 2009;44:82-8.

41. Kung YH, Wu TT, Hong MC, Sheu SJ. Intravitreal tissue plasminogen activator and pneumatic displacement of submacular hemorrhage. J Ocul Pharmacol Ther. 2010;26:469-74.

42. Araujo J, Sousa C, Faria PA, Carneiro A, Rocha-Sousa A, Falcao-Reis F. Intravitreal injection of recombinant tissue plasminogen activator in submacular hemorrhage: case series. Eur J Ophthalmol. 2016;26:e49-51.

43. Hattenbach LO, Klais C, Koch FH, Gumbel HO. Intravitreous injection of tissue plasminogen activator and gas in the treatment of submacular hemorrhage under various conditions. Ophthalmology. 2001;108:1485-92.

44. Coll GE, Sparrow JR, Marinovic A, Chang S. Effect of intravitreal tissue plasminogen activator on experimental subretinal hemorrhage. Retina. 1995;15:319-26.

45. Kokame GT. Vitreous hemorrhage after intravitreal tissue plasminogen activator (t-PA) and pneumatic displacement of submacular hemorrhage. Am J Ophthalmol. 2000;129:546-7.

46. Kamei M, Misono K, Lewis $\mathrm{H}$. A study of the ability of tissue plasminogen activator to diffuse into the subretinal space after intravitreal injection in rabbits. Am J Ophthalmol. 1999;128:739-46.

47. Kimura AE, Reddy CV, Folk JC, Farmer SG. Removal of subretinal hemorrhage facilitated by preoperative intravitreal tissue plasminogen activator. Retina. 1994;14:83-4.

48. Tsuyama T, Hirose H, Hattori T. Intravitreal tPA injection and pneumatic displacement for submacular hemorrhage in a 10-year-old child. Case Rep Ophthalmol Med. 2016;2016:9809583.

49. Holland D, Wiechens B. Intravitreal r-TPA and gas injection in traumatic submacular hemorrhage. Ophthalmologica. 2004;218:64-9.

50. Humayun M, Lewis H, Flynn HW Jr, Sternberg P Jr, Blumenkranz MS. Management of submacular hemorrhage associated with retinal arterial macroaneurysms. Am J Ophthalmol. 1998;126:358-61.

51. Williams DF, Han DP, Abrams GW. Rebleeding in experimental traumatic hyphema treated with intraocular tissue plasminogen activator. Arch Ophthalmol. 1990;108:264-6.

52. Hillenkamp J, Surguch V, Framme C, Gabel VP, Sachs HG. Management of submacular hemorrhage with intravitreal versus subretinal injection of recombinant tissue plasminogen activator. Graefes Arch Clin Exp Ophthalmol. 2010;248:5-11.

53. Fujikawa M, Sawada O, Miyake T, Kakinoki M, Sawada T, Kawamura H, et al. Comparison of pneumatic displacement for submacular hemorrhages with gas alone and gas plus tissue plasminogen activator. Retina. 2013;33:1908-14.

54. Gopalakrishan M, Giridhar A, Bhat S, Saikumar SJ, Elias A. Pneumatic displacement of submacular hemorrhage: safety, efficacy, and patient selection. Retina. 2007;27:329-34.

55. Ohji M, Saito Y, Hayashi A, Lewis JM, Tano Y. Pneumatic displacement of subretinal hemorrhage without tissue plasminogen activator. Arch Ophthalmol. 1998;116:1326-32.

56. Rishi E, Gopal L, Rishi P, Sengupta S, Sharma T. Submacular hemorrhage: a study amongst Indian eyes. Indian J Ophthalmol. 2012;60:521-5.

57. Haupert CL, McCuen BW 2nd, Jaffe GJ, Steuer ER, Cox TA, Toth CA, et al. Pars plana vitrectomy, subretinal injection of tissue plasminogen activator, and fluid-gas exchange for displacement of thick submacular hemorrhage in age-related macular degeneration. Am J Ophthalmol. 2001;131:208-15.

58. Lincoff H, Kreissig I, Stopa M, Uram D. A 40 degrees gaze down position for pneumatic displacement of submacular hemorrhage: clinical application and results. Retina. 2008;28:56-9.

59. Stopa M, Lincoff A, Lincoff H. Analysis of forces acting upon submacular hemorrhage in pneumatic displacement. Retina. 2007;27:370-4.

60. Doi S, Kimura S, Morizane Y, Shiode Y, Hosokawa M, Hirano M, et al. Successful displacement of a traumatic submacular hemorrhage in a 13-year-old boy treated by vitrectomy, subretinal injection of tissue plasminogen activator and intravitreal air tamponade: a case report. BMC Ophthalmol. 2015;15:94.
61. Martel JN, Mahmoud TH. Subretinal pneumatic displacement of subretinal hemorrhage. JAMA Ophthalmol. 2013;131:1632-5.

62. Schulze SD, Hesse L. Tissue plasminogen activator plus gas injection in patients with subretinal hemorrhage caused by age-related macular degeneration: predictive variables for visual outcome. Graefes Arch Clin Exp Ophthalmol. 2002;240:717-20.

63. Shields RA, Ludwig CA, Powers MA, Tran EMT, Smith SJ, Moshfeghi DM. Postoperative adverse events, interventions, and the utility of routine follow-up after 23-, 25-, and 27-gauge pars plana vitrectomy. Asia Pac J Ophthalmol. 2019;8:36-42.

64. Kim M, Kim JH, Seo Y, Koh HJ, Lee SC. Intravitreal bevacizumab for traumatic choroidal rupture. Optom Vis Sci. 2015;92:e363-7.

65. Chanana B, Azad RV, Kumar N. Intravitreal bevacizumab for subfoveal choroidal neovascularization secondary to traumatic choroidal rupture. Eye. 2009;23:2125-6.

66. Karagiannis D, Chatziralli I, Kaprinis K, Georgalas I, Parikakis E, Mitropoulos P. Location of submacular hemorrhage as a predictor of visual outcome after intravitreal ranibizumab for age-related macular degeneration. Clin Interv Aging. 2017;12:1829-33.

67. Cho HJ, Koh KM, Kim JH, Kim HS, Han Jl, Lew YJ, et al. Intravitreal ranibizumab injections with and without pneumatic displacement for treating submacular hemorrhage secondary to neovascular age-related macular degeneration. Retina. 2015;35:205-12.

68. Bardak H, Bardak Y, Ercalik Y, Erdem B, Arslan G, Timlioglu S. Sequential tissue plasminogen activator, pneumatic displacement, and anti-VEGF treatment for submacular hemorrhage. Eur J Ophthalmol. 2018;28:306-10.

69. Iacono P, Parodi MB, Introini U, La Spina C, Varano M, Bandello F. Intravitreal ranibizumab for choroidal neovascularization with large submacular hemorrhage in age-related macular degeneration. Retina. 2014;34:281-7.

70. Gonzalez-Lopez JJ, McGowan G, Chapman E, Yorston D. Vitrectomy with subretinal tissue plasminogen activator and ranibizumab for submacular haemorrhages secondary to age-related macular degeneration: retrospective case series of 45 consecutive cases. Eye. 2016;30:929-35.

71. Papavasileiou E, Steel DH, Liazos E, McHugh D, Jackson TL. Intravitreal tissue plasminogen activator, perfluoropropane (C3F8), and ranibizumab or photodynamic therapy for submacular hemorrhage secondary to wet age-related macular degeneration. Retina. 2013;33:846-53.

72. Sandhu SS, Manvikar S, Steel DH. Displacement of submacular hemorrhage associated with age-related macular degeneration using vitrectomy and submacular tPA injection followed by intravitreal ranibizumab. Clin Ophthalmol. 2010:4:637-42.

73. Shienbaum G, Garcia Filho CA, Flynn HW Jr, Nunes RP, Smiddy WE, Rosenfeld PJ. Management of submacular hemorrhage secondary to neovascular age-related macular degeneration with anti-vascular endothelial growth factor monotherapy. Am J Ophthalmol. 2013;155:1009-13.

74. de Silva SR, Bindra MS. Early treatment of acute submacular haemorrhage secondary to wet $\mathrm{AMD}$ using intravitreal tissue plasminogen activator, C3F8, and an anti-VEGF agent. Eye. 2016;30:952-7.

75. Kitagawa Y, Shimada H, Mori R, Tanaka K, Yuzawa M. Intravitreal tissue plasminogen activator, ranibizumab, and gas injection for submacular hemorrhage in polypoidal choroidal vasculopathy. Ophthalmology. 2016;123:1278-86.

76. Kim JH, Chang YS, Kim CG, Lee DW, Han Jl. Hyperpigmented spots after treatment for submacular hemorrhage secondary to polypoidal choroidal vasculopathy. Graefes Arch Clin Exp Ophthalmol. 2018;256:469-77.

77. Kim JH, Chang YS, Lee DW, Kim CG, Kim JW. Quantification of retinal changes after resolution of submacular hemorrhage secondary to polypoidal choroidal vasculopathy. Jpn J Ophthalmol. 2018;62:54-62.

78. Rouvas AA, Papakostas TD, Ntouraki A, Douvali M, Vergados I, Ladas ID. Photodynamic therapy, ranibizumab, and ranibizumab with photodynamic therapy for the treatment of polypoidal choroidal vasculopathy. Retina. 2011;31:464-74.

79. Chen YY, Lin LY, Chang PY, Chen FT, Mai ELC, Wang JK. Laser and antivascular endothelial growth factor agent treatments for retinal arterial macroaneurysm. Asia Pac J Ophthalmol. 2017;6:444-9.

80. Mizutani T, Yasukawa T, Ito Y, Takase A, Hirano Y, Yoshida M, et al. Pneumatic displacement of submacular hemorrhage with or without tissue plasminogen activator. Graefes Arch Clin Exp Ophthalmol. 2011;249:1153-7. 
81. Abdul-Salim I, Embong Z, Khairy-Shamel ST, Raja-Azmi MN. Intravitreal ranibizumab in treating extensive traumatic submacular hemorrhage. Clin Ophthalmol. 2013;7:703-6.

82. Barleon B, Sozzani S, Zhou D, Weich HA, Mantovani A, Marme D. Migration of human monocytes in response to vascular endothelial growth factor (VEGF) is mediated via the VEGF receptor flt-1. Blood. 1996;87:3336-43.

83. Treumer F, Klatt C, Roider J, Hillenkamp J. Subretinal coapplication of recombinant tissue plasminogen activator and bevacizumab for neovascular age-related macular degeneration with submacular haemorrhage. Br J Ophthalmol. 2010;94:48-53.
84. Heiduschka P, Fietz H, Hofmeister S, Schultheiss S, Mack AF, Peters S, et al. Penetration of bevacizumab through the retina after intravitreal injection in the monkey. Invest Ophthalmol Vis Sci. 2007;48:2814-23.

\section{Publisher's Note}

Springer Nature remains neutral with regard to jurisdictional claims in published maps and institutional affiliations.
Ready to submit your research? Choose BMC and benefit from:

- fast, convenient online submission

- thorough peer review by experienced researchers in your field

- rapid publication on acceptance

- support for research data, including large and complex data types

- gold Open Access which fosters wider collaboration and increased citations

- maximum visibility for your research: over 100M website views per year

At BMC, research is always in progress.

Learn more biomedcentral.com/submissions 